\title{
Manichaean Cues: Religious Identity in Everyday Life
}

The people we have met in the past few chapters juggled several roles. Pamour III was - as far as we can tell - a dutiful son, a responsible elder brother, a sometimes absent husband and father, an eager trader, a Kellite, a migrant, and probably a number of other things that we cannot discern. Other villagers were daughters, potters, mothers, weavers, carpenters, caravan drivers, estate managers, Roman officials, 'Egyptians', 'Hibites', and so on. For some, such as Pamour II I himself, we may add 'Manichaean' to the list. However, the nature of this 'Manichaeanness' is difficult to ascertain. Shared religion is, by and large, not something that the Pamour family or their associates discuss at length: indeed, the main body of evidence for Manichaean affiliation is the literary texts, not the documentary letters. How are we to judge the importance of religious identity to Pamour III and the rest of his associates? And how can we be sure that this identity was 'Manichaean'? These questions will, in various guises, follow us throughout the rest of this book.

The present chapter sets the stage by clarifying some theoretical concepts broached in the introduction, and applying them to a selection of documentary letters. While religious affiliation is never discussed explicitly, authors of House 1-3 did employ religiously charged phrases, allusions, and terms: what we may call 'religious cues'. These cues comprise the best-preserved evidence we have for the way the actors themselves articulated their religious identity. Below, we examine what they tell us about the role of religious identity in the everyday lives of the House 3 inhabitants, and the extent to which they can be taken as belonging to a specifically Manichaean tradition. But before we turn to the House 1-3 material, we need to take a step back and consider some theoretical perspectives on everyday religion and lay identity, in order to situate the present contribution. We therefore start by looking at recent trends in scholarship on late antique religious identity.

\section{$1 \quad$ Religious Identity and Lived Religion}

Sociologists have had 'identity' in their line of sight since the mid-2oth century. The term was popularised in the 196os by among others Erik Erikson and 
Erwin Goffman, and already by the 1970s there were complaints that it had become something of a cliché. ${ }^{\text {S }}$ Still, it has retained its currency among scholars, and identity theory has become a central field of sociological inquiry. The literature on identity has grown quite extensive also within the field of antiquity, especially in the course of the last three decades, influenced by trends in sociology, anthropology, and literary theory. ${ }^{2}$ This 'rise of identity' has coincided with another scholarly development, namely the rejection of essentialist notions of 'religion' ${ }^{3}$ It has led to a dissolution of established assumptions about antique religion. Whereas older scholarship tended to take it as a given that religions were relatively uniform and sharply bounded, and the religious identities of their adherents correspondingly stable, modern scholarship has successfully challenged these assumptions. It has become common to emphasise the porosity of communal boundaries, and notions of situational and fluid identities have given scholars the tools to do so. Sharp boundaries are largely seen as reflecting authoritative discursive constructions rather than realities on the ground. ${ }^{4}$

This turn has received further impetus from an increase in attention to the everyday religious practices of non-specialists, the so-called 'lived religion' tradition within religious studies. Scholars of antique religion working within this paradigm have shifted attention away from abstractions, such as 'Judaism' or 'Christianity', to the specific communities or individuals that appropriated these traditions for their own use, blurring traditional boundaries in the process. ${ }^{5}$ Scholars have grappled with the problem of non-specialist religious

1 Brubaker and Cooper, 'Beyond Identity', 3-4.

2 The oft-cited starting point is Judith Lieu, John North, and Tessa Rajak, eds., Jews among Pagans and Christians (London: Routledge, 1992). The literature on identity has become quite voluminous in the last three decades, and so a few examples have to suffice: Judith Lieu, Christian Identity in the Jewish and Graeco-Roman World (Oxford: Oxford University Press, 2004); Isabella Sandwell, Religious Identity in Late Antiquity: Greeks, Jews and Christians in Antioch (Cambridge: Cambridge University Press, 2007); Zellentin and Iricinschi, 'Making Selves and Marking Others'; Harland, Dynamics of Identity.

3 Smith, Meaning and End; Talal Asad, 'The Construction of Religion as an Anthropological Category', in Genealogies of Religion: Disciplines and Reasons of Power in Christianity and Islam (Baltimore: John Hopkins Press).

4 See Boyarin, Border Lines; Lieu, Christian Identity, 98-146 (esp. 132-46); Sandwell, Religious Identity; Rebillard, Christians and their Many Identities (below).

5 Drawing on studies such as Hall, ed., Lived Religion in America; McGuire, Lived Religion. Examples within the field of ancient religion include Virginia Burrus and Rebecca Lyman, 'Shifting the Focus of History', in Late Ancient Christianity. A People's History of Christianity, vol. 2, ed. Virginia Burrus (Minneapolis: Fortress Press, 2005); Jörg Rüpke, ed., The Individual in the Religions of the Ancient Mediterranean (Oxford: Oxford University Press, 2015); Paul Lichterman et al., 'Grouping Together in Ancient Lived Religion', in Religion of the Roman 
practice in late antiquity by critically appraising the textual evidence, by paying close attention to archaeological material, and by drawing on new sociological trends. Recent studies have emphasised how non-specialists employed religious traditions in idiosyncratic ways, while authorities struggled to affect their behaviour. In his Christians and their Many Identities in Late Antiquity (2012), Eric Rebillard applies concepts drawn from the sociologist Rogers Brubaker to the works of Tertullian, Cyprian, and Augustine, in order to discern how laity acted, or more often refrained from acting, on their Christian identity (which he terms Christianness). He argues that while the clergy sought to impose a hierarchical view of identity, subordinating other identities to that of 'Christian', the laity preferred to arrange their Christianness laterally, i.e. as one of several identities whose saliency was considered on a situational basis. ${ }^{6}$ Christianness was primarily displayed (activated) in church and related contexts, within a distinct religious sphere of social life that only crystallised itself in late antiquity. ${ }^{7}$ On those occasions when Christianness was used successfully to mobilise for collective action, it was chiefly on the instigation of church leaders, and the sense of commonality (groupness) they engendered in the laity was temporary. ${ }^{8}$ For most lay people, religious identity played little role outside distinctly religious contexts. A similar approach has been taken by Mattias Brand for the Kellis material, in his dissertation "The Manichaeans of Kellis' (2019). Building on Rebillard's study, and using Ann Swidler's notion of integrated and segregated cultural repertoires, he has argued that while the Elect could integrate Manichaean repertoires into their daily lives, the lay people of the documentary letters from House 1-3 kept their 'Manichaeanness' segregated from everyday experience. ${ }^{9}$

These studies show how the modern take on identity retains its relevance for antiquity. Even in antiquity, man was never a pure homo religiosus, but simultaneously an inhabitant of many roles. The specific contexts in and concerns with which individuals were engaged shaped their religious life in important ways, and the laity had a high degree of agency in shaping their religiosity. At the same time, it seems to me that these approaches put too much emphasis on the individualist, situationist aspect of identity. The term 'identity', as

Empire 3 (2017); David Frankfurter, Christianizing Egypt: Syncretism and Local Worlds in Late Antiquity (Princeton, NJ: Princeton University Press, 2018); and the works of Rebillard and Brand considered below.

6 Rebillard, Christians and their Many Identities, 3-5.

7 Ibid., 12-20, 69-70, 74-75; for the emergence of religion, see 93-94.

8 Ibid., 92-93.

9 Brand, 'Manichaeans of Kellis', 342-44. 
used among identity theorists, designate those role(s) an individual possesses within a collective that he or she actively appropriates. ${ }^{10}$ Any given identity therefore has a dual nature: it is both individually appropriated and collectively represented.11 These two never overlap completely, and individual identities are certainly not immutable essences. But they are not entirely dependent on circumstance or devoid of coherence, either. Strong situationist frameworks, such as those advanced by Brubaker and Swidler, are not universally accepted in cultural sociology. ${ }^{12}$ Research in the field of identity theory shows that even in modern societies, more extensively compartmentalised than ancient ones, identities as a rule co-mingle, coming into conflict or reinforcing each other, and that individuals arrange their identities hierarchically, giving more salience to some than to others. ${ }^{13}$ For late antique Egypt, David Frankfurter has recently shown that Christianness was appropriated and put into practice in different ways in different mundane spheres of life, what he terms 'social sites.' ${ }^{14}$ While not (for most people) a 'master identity' to which all others were subordinate, Christianness and other religious identities could and did 'spill over', affecting judgements and actions in other spheres of life, as well as being affected by them. As we shall see below, the Kellis material would seem to suggest that displays of 'Manichaeanness', too, were woven into everyday contexts.

10 In this sense, its usage goes back to Nelson Foote (1951). See Burke and Stets, Identity Theory, 38 .

11 For a criticism, see Brubaker and Cooper, 'Beyond Identity', 6-9. Although I find the term 'identity' useful for designating the interface between individual appropriations and collective representations, the critics are right in that the two need to be kept analytically distinct. Below, 'individual identity' is used when emphasising individual appropriations; 'communal' or 'shared' identity when emphasising collective representations.

12 For a critique of Brubaker from within cultural sociology, arguing that he underestimates the role of culture in group-making, see Craig Calhoun, 'The Variability of Belonging: A Reply to Rogers Brubaker', Ethnicities 3 no.4 (2003). For a sustained critique of strong situationist frameworks, such as that of Swidler, from a cognitive angle, see Stephen Vaisey, 'Motivation and Justification: A Dual-Process Model of Culture in Action', in American Journal of Sociology, 114 no. 6.

13 For identity hierarchies, see Burke and Stets, Identity Theory, 53-55, 139ff.

14 Frankfurter employs the concept of syncretism in order to describe this process, arguing that the laity appropriated Christian tradition both by filtering it through pre-Christian, traditional modes of behaviour (which he terms habitus) and creatively combining it with other traditions (which he terms bricolage). This syncretism took different forms at different social sites, such as the home, the workplace, or the local shrine. See Frankfurter, Christianizing Egypt, 15-31. 
Identities are social phenomena, appropriated, reinforced, and disseminated by way of being displayed in social contexts. In order to describe such displays, we shall here employ the concept of 'cues'. This term is used to designate the displays of practical, 'insider' knowledge which allows individuals to manoeuvre social interaction in any given community. ${ }^{15}$ Cues may include bodily gestures, marks, or general appearance, as well as coded symbols, words, and phrases. It is these latter that are left to us in the papyri. The term 'religious cues' is here used to designate those religiously charged words and phrases that were recognised by members of a community and were used to signal religious affiliation. ${ }^{16}$ Some difficulties should be noted at the outset. For one, the same term could be used both as a religious cue and as a cue in other contexts. Thus, 'brother' might signify a co-adherent, even a monk, in some contexts; in others, a colleague or a close associate, as well as a familial brother. Secondly, many religious cues are shared and used in similar manners across different religious communities. This was certainly the case among the Manichaeans, as will be further discussed below. Finally, historians do not have direct access to individual minds. We cannot, for the most part, determine whether usage of religious language reflects internalised religious dispositions, or, for instance, the pressure of social expectations. However, we can seek to understand the rhetorical work that cues were put to. This allows us to analyse the role of shared religious identity within the social formation we are studying.

Ancient letters provide an intriguing arena for analysing religious cues. Letter writing in antiquity was a central activity for those wishing to sustain friendly relations and communal ties. ${ }^{17}$ Cues were used to signal a wide

15 I here draw on the study of Adam Schor, Theodoret's People, 10. An important source for the concept of 'cues' is Bourdieu, Theory of Practice, 10-11. See also the notion of 'symbolic cues', found in Social Convergence Theory, and 'cultural cues', used in a wide range of studies within cultural sociology.

16 To be more specific, we here include self-appellations, names of divinities, metaphors, prayers, devotions, greetings, and scribal markers such as crosses or nomina sacra: words and symbols used more or less intentionally to invoke shared sentiment. This excludes some other features at times used to identify authors as belonging to a specific group, such as personal names, official titles, or festivals mentioned in passing. For discussion of these and other identity markers in the papyri, see Choat, Belief and Cult.

17 For general works on ancient letter writing, see John L. White, Light from Ancient Letters (Minneapolis: Fortress Press, 1986); Stanley Stowers, Letter Writing in Greco-Roman Antiquity (Philadelphia: Westminster Press, 1986); and Hans-Josef Klauck and Daniel P. Bailey, Ancient Letters and the New Testament: A Guide to Context and Exegesis (Waco: 
spectre of identities, ranging from those widely shared to those shared only by tight-knit communities. Their usage was well understood by ancient letter writers. (Pseudo-)Demetrius, to whom the first known treatise on letter writing is attributed, maintained that proverbs should be employed to enhance the beauty of a letter, since they were widely known. ${ }^{18}$ Such 'proverbial knowledge' was shared by most literate Romans, and so a safe bet when wishing to emphasise common ground between writer and recipient. Less inclusive cues include quotations from, allusions to, or even especially archaic terms or modes of speech derived from ancient poets and writers - Homer in particular - which well-educated elites of the Roman Empire used to signal their shared educational background, their paideia, tying the dispersed elites of the Empire's cities together through common culture. ${ }^{19}$ Christians employed scriptural quotations or allusions to signal shared identity, and bishops could even employ specific doctrinal terms in order to mark shared theological commitments. ${ }^{20}$ These identities were certainly not mutually exclusive: Christian authorities from elite backgrounds would continue to signal their paideia well into late antiquity. $^{21}$

Yet, not all letters needed distinct identity markers. The families of House 1-3 were not prominent figures writing for a public audience, and their letters were, for the most part, not carefully sculptured literary products. Most belong to the category of mundane communications that predominate in the papyrological material. ${ }^{22}$ As Malcolm Choat has shown, unambiguous displays of religious identity are far from ubiquitous in papyrus letters. ${ }^{23}$ After all, such letters were largely written for contexts (familial, economic, or collegial) where religious affiliation could safely be ignored, taken for granted, or relegated to the backdrop. Even correspondences conducted by religious specialists, such as Christian monks, did not necessarily call for elaborate displays of religious

Baylor University Press, 2006). For their role in constructing communities, see Paola Ceccarelli et al., eds., Letters and Communities: Studies in the Socio-Political Dimensions of Ancient Epistolography (Oxford: Oxford University Press, 2018).

18 Klauck and Bailey, Ancient Letters, 186.

19 See, in particular, Peter Brown, Power and Persuasion in Late Antiquity: Towards a Christian Empire (Madison: University of Wisconsin Press, 1992).

20 Choat, Belief and Cult, 74-10; Blumell, Lettered Christians, 36-85; Schor, Theodoret's People, 22-25. See further below.

21 E.g. Brown, Power and Persuasion, 44-70.

22 To be sure, the division between 'literary' and 'documentary' letters should be understood as a matter of degree rather than kind; see e.g. Klauck and Bailey, Ancient Letters, 68-70. Choat, Belief and Cult, 15-16, 152ff. 
rhetoric. ${ }^{24}$ Some cues, such as 'greetings in the Lord', became stock phrases, widespread in letters written by Christians regardless of topic, but more extensive usage was not generally considered appropriate or necessary. The instances in which more elaborate religious cues were employed should therefore draw our attention all the more, as they provide insight into those particular settings or social groupings in which religious identity was actively made to play a role.

Religious Cues in the Circles of House 3

In the following, we consider religious cues from some prominent lay authors of the House 3 circles and the contexts in which they occur. They serve to exemplify the religious language of the private letters, and as points of departure for discussing the role of religious identity for the authors. On a general level, we may note the comparative abundance of cues found in the House 1-3 letters. As pointed out above, usage of religious cues in private letters is by no means the norm in preserved papyri. Of the private letters from House 1-3, more than $6 \circ \%$ contain religious cues. ${ }^{25}$ Most are found in the letter openings, the initial part of a letter containing the inner address (the prescript) and other polite niceties, such as prayers for good health, remembrances, and other greetings (the proem), that preface the letter body, although a few letters also feature religious cues in the letter body and/or the letter closings. ${ }^{26}$ They range from stock phrases (such as 'greetings in the Lord'), to more distinct greetings, to elaborate performances that string together several cues. While the most distinctive ones occur in the Elect 'Father letters' (for which, see Chapter 8, Section 2.3), some lay letters also feature more elaborate performances.

As we saw, Rebillard has argued that Christianness did not, as a rule, have salience for the laity outside of specifically religious contexts, when dealing with rituals or prompted by religious authorities. If this is to hold for Manichaeanness among the laity at Kellis, we would expect such elaborate cues to be restricted to those letters concerned with religious subject matters. In order to determine this, we need to examine the relationship between religious cues and letter contents. This is not as straightforward as it may seem.

24 Malcolm Choat, 'Monastic Letters on Papyrus from Late Antique Egypt', in Writing and Communication in Early Egyptian Monasticism, ed. M. Choat and Maria Chiara Giorda (Leiden: Brill, 2017), 46-48.

$25 \quad$ C.75 out of 120 , by my (rough) reckoning. The percentage of letters with religious cues was very likely higher, considering the loss of openings in several of the letters included in the total.

26 For an overview, see Klauck and Bailey, Ancient Letters, 9-42. 
Our lack of knowledge of the specific thrust of an author's reasoning, as well as the lacunose nature of many letters, often present formidable obstacles to determining whether a topic is 'religious'. Another element that must be taken into account is the possibility of scribal influence. It was common for authors in antiquity - even literate ones - to make use of trained scribes. The authors of House 3 were no exceptions. ${ }^{27}$ It could be that the cues found in the material tell us more about the training of the scribes than the intents of the authors, as stock greeting phrases, such as those employed in letter openings, were often dictated by scribal conventions. ${ }^{28}$ We need, then, to consider several well-preserved letters by the same author, furnished with more distinctive or elaborate religious cues, with different hands evincing different scribes. Luckily, several authors do provide such material: Makarios, Horion, Pamour III, and Pekysis. Their letters allow us to compare cue usage both within an author's own dossier, and between different authors. They are examined here together with a single letter by Tekysis III.

\subsection{Religious Cues and Religious Matters: Horion and Makarios}

The lay letters that contain the most distinctive or elaborate examples of religious cues are those found in the circle of Maria/Makarios and of Tehat/ Horion. ${ }^{29}$ Starting with the letters by Makarios, religious cues are found in the openings of P.Kellis V Copt. 19, 20, and 22, i.e. about half of his preserved letters. Of the rest, P.Kellis v Copt. 21 restricts itself to a greeting 'in the Lord', while the openings of two others, P.Kellis v Copt. 24 and 52, are not preserved. All these letters feature Maria I as an addressee, although they include other addressees as well: Matthaios is the primary recipient of P.Kellis V Copt. 19, while P.Kellis v Copt. 20, 21, and 22 feature the couple Psenpnouthes and Kyria as co-recipients.

The usage of cues in Makarios' letters is generally tied to religious affairs that he and his associates in the Nile Valley are engaged in. In P.Kellis v Copt. 19, Makarios' cues are used to praise the young Matthaios. He opens with an

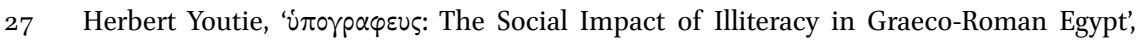
Zeitschrift für Papyrologie und Epigraphik 17 (1975). For the House 3 material, see P.Kellis $V I I, 11$.

28 Choat, Belief and Cult, 23. For a (possible) example of scribal stylistic influence, see T. V. Evans, 'Linguistic Style and Variation in the Zenon Archive', in Variation and Change in Greek and Latin: Problems and Methods, ed. Martti Leiwo, Hilla Halla-aho, Marja Vierros (Helsinki: Suomen Ateenan-Instituutin säätiö, 2012), 25-40.

29 On the assumption that these are indeed laity. For a discussion of the case of Horion, see Choat, 'Monastic Letters', 55-56 n. 228. 
elaborate address: 'The child of righteousness; the one whose good reputation is in my mouth at every moment, whose witness is permanent in my heart; the name sweet in my mouth, my beloved son' (ll.1-3). He continues with a remembrance, saying: 'I remember your gentleness and your calm, and the example of your [...] propriety' (ll.4-5), before invoking the Paraclete (i.e. Mani): 'Now, be in worthy matters; just as the Paraclete has said: "The disciple of righteousness is found with the fear of his teacher upon him (even) while he is far from him, like (a) guardian (?)"' (1l.8-11). ${ }^{30}$ Finally, he exhorts Matthaios to be mindful of his studies, and continue his readings and exercises dealing with religious literature. The letter body concerns more practical matters, addressed primarily to Maria I and mostly relating to a journey that Matthaios is making to the Nile Valley. This stay in the Valley, also documented by Matthaios' own letters, involved copying religious books and associating with a Manichaean authority known as the Teacher. Makarios' cues appear intended to reinforce Matthaios' identity as a dutiful and educated adherent (perhaps even as an aspiring Elect), in order to make sure he prepares properly for his stay in the Valley.

The letters addressing Psenpnouthes, Kyria, and Maria I are written by scribes. ${ }^{31}$ They display a wide range of religious cues, and it is likely that Makarios dictated them. As Malcolm Choat has observed, 'such is the unusually deep religious tone and content of the greeting formulae, and their variation, that he almost certainly composes them himself.'32 P.Kellis v Copt. 21, introduced only with the formula 'in the Lord', is a rather short letter. It is concerned with other letters that Makarios has forwarded to Kellis by way of Apa Lysimachos, various objects he has (or should have) received, as well as requests for textiles and thread. The greeting would seem to fit the briefness of the content. P.Kellis V Copt. 20 and 22, on the other hand, are longer pieces. The former opens by addressing the addressees with the greeting: 'my masters, my brethren, my loved ones who are honoured of my soul', adding 'in the Lord, I greet you' (P.Kellis v Copt. 20, 1l.1-5). It continues with a prayer: 'This is my prayer at all times unto God: That freedom will come about for us, to come and see you again while we are in the body' (ll.5-9). In the letter body, Makarios starts by criticising Maria for not assisting ('remembering') him and his companions, and by emphasising his own concerns. He wonders whether her negligence may be due to the absence of his children. Matthaios is expected back (the text is fragmented and the reason for his absence unclear), while his brother

\footnotetext{
30 For this rendition, see Gardner, 'Letter from the Teacher', 321.

$31 \quad$ P.Kellis $V, 156$.

32 Choat, Belief and Cult, 26-27.
} 
Piene is on the road, travelling with the Teacher. He also relates that a petition for getting the things of Matthaios back from a certain Kleobolous is underway. In general, the events do not clearly pertain to religious matters. However, the opening prayer for 'freedom' may well relate to difficulties that Makarios is experiencing, as the editors carefully suggest. ${ }^{33}$ Although not certain, it may well be that this should be seen in light of the problems of Matthaios, and that the conflict had a religious component - as is the case in P.Kellis v Copt. 22, containing a similar opening prayer.

P.Kellis V Copt. 22 itself starts with a greeting to Psenpnouthes I, Kyria I, and Maria I in Greek, but shifts to Coptic mid-sentence when adding 'mother' Tamouienia, and continues with a string of quite distinctive cues:

[Gr.] To my masters and most honourable brothers (and sisters): Pesempnouthes and Kyria and Maria, [Copt.] and your children by name, and my mother Tamouienia; you who are the good care-takers, zealous in every good thing, the children of the living race, the fruit of the flourishing tree and the blossoms of love. It is I, Makarios; in the Lord, - greetings. Before everything: I greet you warmly. Your ineffaceable memory is in my heart at all times; and I am praying to God that he may grant us freedom and we may greet you again in the body. (ll.1-11)

This opening is quite extraordinary. How does it relate to the letter content? In the first part of the letter (ll.11-6o), Makarios describes various goods that he has received, and expresses reproach for others that he has not. He also berates them for negligence relating to a complex set of transactions, one relating to wages and economic loss, another to travel fares. Their context is hard to determine. A change of topic follows. Makarios turns to a new set of oblique difficulties, evidently tied to religious matters. One is a conflict relating to a book. In one passage, unfortunately preceded by several lacunose lines, Makarios berates either Kyria I or Maria I for failing to provide proper support in this conflict: 'How many ... these or our sanctuary? Are not you yourself a catechumen? For we are not retaliating against anyone in this place for what they are doing to us' (ll.6o-62). The other involves problems that a family member was experiencing, in connection with which Makarios continues his criticism:

33 They note: 'The wish for future $\pi \alpha p p \eta \sigma i \alpha$ might suggest that Makarios is at the moment of writing under some constraint. He expresses a similar wish in 22. Further evidence that he feels constrained might be the generally reproachful tone of the letter'. P.Kellis $V, 169$. 
You had no pity on me. You had no pity for your brother's son, because he is under persecution ( $\triangle 1$ IOrMOC); though you know that I have spent two years without him. He has no one who can guide him but God, the one who repays $[. .$.$] some clothes, for what has he done for him? (ll.72-76)$

The implications of these passages for tensions between the community and the wider social world are treated in Chapter 6 . Here it suffices to say that Makarios' language strongly suggests a religious context for these (related?) events: in particular, by using the term 'catechumen', Makarios invokes the set of obligations tied to this role within a (Manichaean) religious context. ${ }^{34}$ In turn, the religious nature of the conflict, and the criticism that Makarios levels at the recipients for not providing enough support (along with the apparent urgency of his situation), probably explains the extra care that has been taken to furnish the opening with elaborate religious cues. By highlighting their shared religious identity, Makarios sought to spur the recipients into giving the help that he considered them obliged to provide as Auditors.

Turning to Horion, we find that he, too, often uses religious cues in the context of religious activity. Religious cues are primarily found in his three letters to Horos I (P.Kellis v Copt. 15-17). The most elaborate is the opening of P.Kellis v Copt. 15, quoted in the Prelude:

To my brother, my master; the loved one of my soul and my spirit. The child of righteousness, the good limb of the Light Mind. The name which is sweet in my mouth, my beloved brother Hor. It is I, Horion; in the Lord God, - greetings. (ll.1-5)

Horion further extols Horos' 'gentleness' and 'immutable, never changing love' (ll.12-13), and he closes the letter with a greeting to 'they who give you rest, the elect and the catechumens, each one by name' (1l.27-30). In the letter body, Horion reassures Horos that he has completed tasks that Horos has requested, including acquiring oil, buying wheat, and sending a jlge (cloth bag?), all as far as can be determined linked to organising something he calls the agape. It is clearly a form of religious charity, and there is to my mind good reasons for taking the agape to be Manichaean food-alms, given to the Elect for their meal (see Chapter 8, Section 2.4). It seems, then, that Horion's greetings are linked to this institution, serving to set what follows apart as pertaining to specifically religious

34 I here disagree with the interpretation offered by Brand ('Manichaeans of Kellis', 16o); see the discussion of open and bounded identity in Chapter 6, Section 4. 
matters. A related letter, P.Kellis V Copt. 16 , is written by the same scribe. ${ }^{35}$ It begins:

To my brother, [my] loved one who is precious to my spirit, and the beloved of all my limbs. The one for whom I wish with all my heart, my true guileless friend. My brother, my master, Hor. It is I, Horion, I greet you; in the Lord God, - greetings. (ll.1-9)

Despite being written by the same scribe, its opening is very different, lacking the conspicuous phrases 'child of righteousness' and 'good limb of the Light Mind'. It does, however, feature the closing greeting 'to the Elect [and the catechumen], all they who give rest to you' (ll.40-41). The letter body is unfortunately very fragmentary. Horion seems to be agitated: he is 'astonished', 'begs', and 'needs' (ll.17-19), and the word 'grief' ( $\lambda \curlyvee \Pi[\mathrm{H}])$ can be read (1.37). But without a clearer understanding of the matters at hand, the context for the opening cues cannot be established. Moving on to the third letter, P.Kellis v Copt. 17, it is written by a different scribe than the two previous. ${ }^{36}$ Its opening reads:

To my brother, my master, precious to me. The sweet name in my mouth at all times, of whose gentleness I bear memory at every moment. My beloved brother Hor. It is I, Horion, I greet you warmly; in the Lord, greeting. (1l.1-8)

While somewhat different from the others, Horos' 'gentleness' is again emphasised (as in the body of P.Kellis v Copt. 15), the phrase 'sweet in the mouth' recurs, and its closing greeting features 'the catechumens and they who give rest to you' (ll.52-53). The fact that 'gentleness' (MNT2入GHT) occurs both in the body of P.Kellis v Copt. 15 and in the opening of P.Kellis v Copt. 17, written by different scribes, indicates that we here have a virtue that Horion himself wanted to stress when addressing Horos. ${ }^{37}$ While the cues of this letter are less distinctive, the body of the letter again deals with preparations of agape, perhaps indicating that the subject matter influenced the choice of cues.

Conversely, the letters to Tehat and Hatres - P.Kellis v Copt. 18 and P.Kellis VII Copt. 58 , both written in the same, coarse hand, ${ }^{38}$ - do not contain

\footnotetext{
35 P.Kellis $V$, 140.

36 P.Kellis $V$, 140 .

37 This virtue is also invoked in a few other Kellis letters, but is by no means common: it is used by Makarios (P.Kellis v Copt. 19, l.5), Matthaios (P.Kellis v Copt. 26, l.11), and the Teacher (P.Kellis viI Copt. 61, l.7). See below.

$38 \quad$ P.Kellis $V$, 152; see also P.Kellis VII, 2 o.
} 
elaborate religious cues, although admittedly only P.Kellis v Copt. 18 has preserved the opening. It reads simply: 'to my loved brethren Tehat and Hatre. It is I, Horion, - in the Lord, greetings' (ll.1-2). Perhaps the difference could be attributed to a difference between the scribes (these letters could be written in Horion's own hand, in contrast to those to Horos I), but, as pointed out above, the internal variation in the letters to Horos are not dependent on scribal influence. Thus, the fact that P.Kellis v Copt. 18 and P.Kellis viI Copt. 58 mainly deal with textile transactions might suggest that while Horion considered the topic of the agape to demand elaborate religious cues, he thought his business letters did not. This would seem to support the findings from the letters of Makarios: that extensive use of religious cues was confined to letters explicitly concerned with religious matters.

However, at least some of the transactions in the letters to Tehat/Hatres do relate to religious matters. This is most evident in the case of the textile work that is ordered on behalf of Saren 'the presbyter', who feature in both letters, but possibly also other instances such as a donation to the 'brothers' (see Chapter 8, Section 2.4). These matters are perhaps more peripheral to the letters' chief concerns than are the preparation of agape at the centre of P.Kellis v Copt. 15 and 17, but suggest that his cue usage is more complex than it would appear at first glance. Moreover, another explanatory factor can to my mind be adduced, in the status difference between the recipients. The letters to Horos I include expressions of gratefulness for letters he has received and discussion of family members, as well as greetings from mother Taese and son Aetios. Little can unfortunately be read of the closing greetings to Tehat and Hatres in either letter, but the tone of Horion's letters to them, with their many orders, is markedly less personal. They give the impression that Tehat/Hatres are junior associates, or at least equals: figures less in need of flowery language than Horos I. Matters of status and personal relationships probably factored into Horion's cue usage.

\subsection{Religious Cues in Everyday Correspondence: Pekysis, Pamour III, Tekysis II}

While providing the most distinctive instances, Makarios and Horion were by no means the only authors who employed more extensive religious cues in their letters. The chief protagonists in the circle around the Pamours present us with several examples. Let us start with the letters of one of the key figures in Chapter 3, Pekysis. His letters are, as remarked there, primarily concerned with business. Still, while two of his letters contain no religious cues at all (P.Kellis VII Copt. 75, P.Kellis I Gr. 76), most have at least one. In three letters, his usage is admittedly limited to fairly common and broadly 'Christian' cues, 
such as 'in the Lord' (P.Kellis viI Copt. 73, 77; P.Kellis I Gr. 72), but three letters are also furnished with more elaborate cues, in the form of opening prayers: P.Kellis VII Copt. 76, 78, and 79 .

In the following, we focus on the latter two, whose recipients and contents are very similar. Starting with P.Kellis viI Copt. 78, its opening reads: 'I pray to God that he will keep you healthy at all times in your body, your soul and your spirit; until I see you again and my joy is complete' (ll.6-12). This is a variation on the so-called 'tripartite prayer' attested in many other letters. ${ }^{39}$ There is otherwise nothing in this particular letter that suggests a specifically religious context that explains the usage. The letter body deals with purchase of papyri, collection of a payment, shipments of goods, and textile work involving family members and business associates. What, then, may have prompted it? Perhaps it could be argued that the prayer was added by the scribe, having little to do with Pekysis' intentions. However, the opening prayer here is very close to that found in P.Kellis VII Copt. 79 (although omitting 'body'), written by a different scribe. ${ }^{40} \mathrm{~A}$ more plausible explanation is to be found in the recipient himself. Among the letters of Pekysis, Horos I is main recipient in all those letters that also contain prayers. He was clearly a senior associate who commanded respect, and it would seem that displays of religious identity was particularly called for in letters addressed to him. ${ }^{41}$ The 'religiousness' of the letter contents did not factor into it. This is supported by the one letter of his that explicitly deals with matters of the Church: P.Kellis VII Copt. 73, addressed to Psais III. The subject here is a 'service to the Church' (ll.16-17), a matter relating to 'life eternal' (ll.23-24), probably the donation of two girls as Elect novices (see Chapter 8, Section 2.2). This pious act would certainly be seen as belonging to the specifically 'religious' sphere. Nonetheless, this letter features no cues beyond a standard greeting 'in the Lord'.

Turning to the letters of Pamour III, they generally have a stronger element of piety than those of his brother. None of his well-preserved letters are devoid of some form of religious cue. ${ }^{42}$ Three of them provide longer prayers, namely

39 Including those of Mani himself. Its usage in Manichaean circles is highly likely to derive from him, although Mani himself, in turn, drew on Paul. See below.

P.Kellis VII, 112-13.

41 Similarly, all of Horion's letters to 'brother' Horos are furnished with religious cues, strengthening the identification of this figure with Horos I (see above).

42 This statement needs some clarification, as several documents might be taken to the contrary: P.Kellis viI Copt. 64, 68, 69, and 70. However, these can be accounted for. P.Kellis VII Copt. 64 and 68 are fragmentary, both missing the openings where such cues would normally be placed. P.Kellis viI Copt. 69 is a contract rather than a private letter. Finally, P.Kellis viI Copt. 70 lacks clear-cut religious cues, but its authorship is not certain, 
P.Kellis VII Copt. 65, 71, and 72. In contrast to those of Pekysis, the letters with prayers are addressed to different figures, all of whom are close relatives or junior associates of Pamour III. Two of them, P.Kellis VII Copt. 65 and 71, open with similar tripartite prayers to those of Pekysis', but are furnished with an extra prayer for protection against evil forces. Thus, the opening of P.Kellis VII Copt. 65, addressed primarily to Pekysis, reads:

[I] pray to the Father, [the God of truth], that you will live [for a long] time; being [healthy in the body], rejoicing [in the spirit], healthy in the [soul, safe] from the snares of the devil and the adversities of Satan $(11.7-15)^{43}$

Its contents are wholly preoccupied with business, including criticism of father Psais (II) for wrongly trying to collect money from Pamour. The second letter, P.Kellis viI Copt. 71, is addressed to Pamour III's sister-in-law, Partheni II. She is greeted with her children, 'especially my son Andreas' (l.3). Thereupon follows:

Before everything: I pray to the Father, the God of Truth, that you will live for me a long time and a great period, being healthy in the body, flourishing in the soul and rejoicing in spirit, safe from all the temptations of Satan and the adversities of the evil place (ll.4-9)

The letter body deals with preparations for a journey that Partheni is about to make to the Nile valley, as well as an attempt to intervene in a quarrel that she and her associates in the Oasis had provoked. The background of the prayers in these letters, then, can be neither the status of the recipients nor the religious nature of the content, nor are they written by the same scribe. It could, perhaps, be significant that both contain rebukes. In both letters, Pamour criticises the recipients for bad conduct. The prayers may have been used to bolster Pamour's authority while striking up a more serious tone - particularly as both add warnings against $\sin$ ('snares of the devil' and 'temptations of Satan') to the tripartite formula. ${ }^{44}$

Pamour III's most extensive prayer, found in P.Kellis vII Copt. 72, diverges substantially from the others surveyed so far, despite the fact that this letter was probably written by the same scribe as P.Kellis VII Copt. $71 .{ }^{45}$ It is not

and it does contain the phrase 'whose name is sweet [in my mouth]', which could be a Manichaean cue (see below).

43 For the reconstruction of the text, see P.Kellis VII, 5 .

44 Such warnings were part of Mani's own style (see below), but could clearly be included or omitted based on the author's needs.

45 P.Kellis VII, 70-71. 
tripartite, and has what seems to be a more personal touch. After greeting the primary recipients, Psais III and Theognostos, 'in God', Pamour adds:

I am praying to the Father, the God of Truth, for your health; your brotherhood in which there is no guile. For no one knows the love for you that pierces my heart, save God alone. He is the one who knows the love with which I am looking out for you and wanting to see you; but since you are far from me, I will not be able to see you. Instead, I am writing to you (sg.)

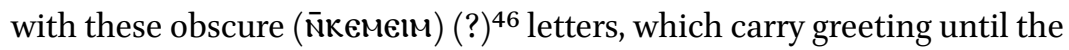
time when face greets face (ll.4-12)

In addition to sharing scribe, the content of this letter also has affinities with P.Kellis viI Copt. 71. It, too, contains a rebuke, criticising Psais III for unworthy behaviour and asking him to pay a debt. Yet, the opening is very different, and the more positive tone set by this prayer seems less suited to reinforce a reproach. Other possibilities are at hand, however. For one, the influence of his current company may have played a part. The letter ends with greetings: 'from those of Apa L(ysimachos?) and Hor: Greet my brother Pshai warmly. Jpnoute, the woman from Tanaietou; her two brothers; the deacon; they all greet you' (ll.35-36). The presence of Elect - Lysimachos and a deacon - may have prompted Pamour III to take a more pious approach. However, another, more personal reason likely provides a better fit. In a passage towards the end of the letter, Pamour III writes that he has just emerged from illness: 'I have been ill for five months; by the grace of God I have recovered. Live, and be of good health for me for a long time' (ll.33-34). Clearly, Pamour had not seen Psais III and Theognostos for quite a while. ${ }^{47}$ His sickness could have provided the background for the strong expressions of longing, and the initial emphasis on health and brotherhood, in this prayer.

Our final example is P.Kellis viI Copt. 115. This letter is addressed to Psais III, and so grouped together with other letters of the Psais/Andreas circle, but it is written by Tekysis - probably Tekysis III, sister of Pamour III, Pekysis, and probably Psais III himself. Psais III is recipient of several letters with religious language by different authors. ${ }^{48}$ The letter of Tekysis III is one of a few in

$46 \quad$ For a discussion, see P.Kellis VII, 8o.

47 Pamour does relate (in an unfortunately fragmentary part) that he is sick also in P.Kellis VII Copt. 71. However, this letter has a different set of recipients. See P.Kellis VII, $71-72$.

48 See e.g. the above-examined P.Kellis vir Copt. 72, Ouales' P.Kellis v Copt. 35, and Ammon's P.Kellis v Copt. 37 . 
the archive with female authorship. Unfortunately, it is the only one preserved by her, so no comparison of cue usage in other letters by her can be made. Still, the letter remains interesting in light of its contents. Its opening runs:

To my master, my loved brother who is greatly honoured by me: The one whose name is sweet in my mouth at all times; while I am praying to embrace him in the body, and my joy will be complete. My brother Pshai: I, your sister Tegoshe, am writing to you in the Lord; - greetings (ll.1-8)

In addition to this opening, employing the embrace-formula elsewhere often combined with the tripartite prayer, her letter features a closing greeting to 'everyone who gives rest to you' (ll.41-42), which is likely to be a distinctly Manichaean greeting (see below). The letter body contains a sorrowful complaint about different ills that have befallen her: the death of 'the children of Nonna, her own inability to travel due to having developed pus, and, not least, the distressing death of a close relative (daughter?) referred to as 'the little girl' (ll.13-30). She ends with a dramatic closing greeting: 'And my son Andreas will bear witness to you (sg.) of all the news and the state I am in, and he will tell you about my life's course' (l.44tr).

Scribal influence is here possible, although the scribe uses the third person in the opening ('I am praying to embrace him', еï $\lambda$ H $\lambda$ доүас)Tч), perhaps suggesting that he was taking down Tekysis' spoken words. ${ }^{49}$ To be sure, the cues that frame her complaints are not as elaborate as some of those employed by her brothers. Nor do they seem to be tailored to her specific situation. However, they do furnish the letter with a more solemn tone than an ordinary greeting 'in the Lord' would have done. It seems reasonable to suggest that religious cues were used in order to set the letter apart, adding emphasis to the gravity of the news it carried.

\subsection{Summary}

In conclusion, we have found that while the religious cues in these letters clearly belong to a specific repertoire, with many recurring words and phrases, they were not simply stock scribal formulae, with no relation to the content, nor were they reserved institutional, 'religious' matters. Rather, the authors themselves had much agency in adapting them to the purpose of their letter.

49 Presumably, Tekysis spoke of Psais in the third person while relating the content of the letter to the scribe. A similar feature can be found in P.Kellis vir Copt. 71; see P.Kellis $V I I, 76$. Admittedly, Tekysis phrasing here is relatively common. 
As we might have expected based on Rebillard's argument, the lay letters that most explicitly deal with religious matters also contain the most elaborate examples of religious cues, namely the letters of Makarios. However, religious matters did not always require cues, as seen in letters by Horion and Pekysis. Not least, religious cues were clearly not restricted to religious contexts. We find distinctive cues and even elaborate performances used in more mundane contexts: to signal respect for specific individuals, to give emphasis to longing for distant family members, to bolster one's gravitas when chastising misconduct, and to frame expressions of sorrow. It is clear that the authors of House 3 saw their religious identities as something that could be activated outside of specifically religious contexts.

\section{Manichaean Cues}

Up until now we have bracketed the question of the religious repertoire that the above-examined cues are drawn from. Religious cues are, as pointed out above, not very common in the papyri, but even where they are in evidence, assigning the author to one or the other religious tradition is a difficult task. Scholarly work on religious affiliation in the papyri has, unsurprisingly, been dominated by the hunt for markers that identify distinctly 'Christian' documents. An important study was Guiseppe Ghedini's Lettere cristiane (1923), which attempted to establish criteria for what constituted Christian markers. His list included phrases expressing monotheistic belief, certain epistolary formulae, use of nomina sacra, and the presence of ecclesiastical titles. However, these criteria have long been contested, and debate concerning how to interpret specific terms and phrases is still ongoing. ${ }^{50}$ In particular, Malcolm Choat's work on fourth-century papyri has shown the difficulties in attempts to infer adherence to a specific religious tradition from these criteria. ${ }^{51}$ Still, certain phrases, such as 'greetings in the Lord (God)', remain widely acknowledged to represent distinctly Christian markers. ${ }^{52}$

50 For a discussion of the historiography, see Blumell, Lettered Christians, $32-36$. So, for instance, taking monotheistic 'formulae of belief' as a Christian marker has been strongly criticised, among others by Choat and Nobbs, 'Monotheistic Formulae', $5^{\mathrm{O}-51}$.

See Choat, Belief and Cult, 12-15. As Blumell notes: 'The upshot of Choat's work is that it shows how devotees of different traditions typically employed the same, or in many cases similar language, to express religiosity in documentary texts, thus disposing of the view that by the fourth century Christians had effectively created a unique discourse that allows their literature to be easily distinguished and identified.' Lettered Christians, 36 . 
Regarding Manichaean letter writing, work has only recently gotten under way, much thanks to the discoveries at Ismant el-Kharab. Here, uncertainty has been expressed concerning the extent to which these lay letters actually indicate a distinctly 'Manichaean' affinity. ${ }^{53}$ The language of the letters is infused with epistolary conventions that suggest rather a mainstream Christian background. The phrase 'greetings in the Lord' is a commonplace at Kellis, two letters not examined above invoke Christ explicitly, and several speak of the 'church' (eאK入HCld), both in the sense of abstract communality - the 'Holy Church' - and of a concrete congregation or place. ${ }^{54}$ It is clear that the authors drew on terminology from the broad Christian tradition to conceptualise their religious community. Yet, do they show that Manichaean identity at Kellis 'in reality' was Christian?

It may initially be noted that whether - and if so, to what extent - the term 'Christian' was used internally remains unclear. ${ }^{55}$ This term is not found as a self-designation in the private letters of the Pamour family, nor in that of any of their close associates. There is only one occurrence of a man self-identifying as a Christian: in P.Kellis I Gr. 48, dated 355, a certain Valerios son of Sarapion released a female slave named Hilaria through a contract of manumission, because of his 'exceptional Christianity'. This Valerios' relationship to the House 1-3 circles is unclear. The name Valerios occurs in a Greek letter, perhaps as a business partner or patron of Philammon II. ${ }^{56}$ He could, perhaps, be the father of Pausanias son of Valerios, the Oasis magistrate active in the 320s-3os and recipient of the 'Father' letter P.Kellis I Gr. 63 - although he would in that case have been quite elderly by the time of this manumission. It is possible that the presbyter who serves as a witness for the manumission could be identified as an Elect official (see Chapter 8, Section 3.4). If it is indeed Manichaean affiliation that Valerios here frames in terms of 'Christianness', he is still signalling it to a public audience (including officials who might use the document in a future legal dispute) rather than private associates. Self-identification as 'Christians' in primarily public displays are similarly found for Augustine's Manichaean opponents. ${ }^{57}$ Even so, given the terms and invocations already adduced, it remains likely that the Pamour family

\footnotetext{
53 See the discussion of the literary remains in Chapter 7 .

54 For the invocation of Christ, see P.Kellis v Copt. 25, P.Kellis vir Copt. 61; for church in the abstract, P.Kellis v Copt. 31, 32, and P.Kellis viI Copt. 73; and for a specific church congregation, P.Kellis v Copt. 25 .

55 For a discussion, see Pedersen, 'Manichaean Self-Designations'.

$5^{6} \quad$ P.Kellis I Gr. 64; note also the recipient of the underlying text of Tehat's letter P.Kellis V Copt. 43 .

For them, see Pedersen, 'Manichaean Self-Designations', 182-88.
} 
considered themselves to be practicing some form of 'exceptional Christianity', even if they did not normally phrase it in such terms.

Yet, as argued in Chapter 1, a self-understanding as 'Christian' does not imply absence of 'Manichaeanness'. Christian concepts and terms such as 'Holy Church' are common in Manichaean literature. The issue of contention is rather to what extent these lay authors saw their Christian affiliation through a Manichaean lens. To this point, it has been pointed out that the private letters do not refer to Manichaean doctrinal terms or mythology. In the introduction to the first volume of documentary texts, the editors commented that:

... it is noteworthy that the complicated details of cosmology, and the various series of emanated gods, hardly intrude into the daily writings as represented here. This is hardly surprising, if one is dealing with the incidental documents of catechumens. It would appear that the more esoteric elements of Mani's gnosis were of most concern to the elect and the heresiologists; and this should not mislead us in a study of the actual faith of these villagers, for whom Manichaeism is perhaps best described as a superior and more effective kind of Christianity. ${ }^{58}$

Similarly, Timothy Pettipiece has contrasted the elaborate rhetorics of the Berlin Kephalaia with that of the laity at Kellis, noting that 'the Manichaean documents recently discovered at Kellis from the so-called "Makarios family" (who are thought to be catechumens) display little awareness or even interest in such erudition. ${ }^{59}$ The implications seem to be that since such knowledge was the preserve of the Elect, the laity did not have much in the way of distinct Manichaeanness.

It is true that such technical language is largely - but, as we shall see, not completely - absent from the Kellis letters. However, I do not think that this view can be maintained. In part, it rests on mistaken expectations. As pointed out above, even where one finds religious cues in the documentary papyri, they seldom constitute elaborate performances. One would certainly not expect to find the level of 'lore' preserved in the Kephalaia literature in mundane communications. At the same time, while doctrinal terms and myths are

$5^{8} \quad$ P.Kellis $V, 79$.

59 Timothy Pettipiece, 'Rhetorica Manichaica: A Rhetorical Analysis of Kephalaia Chapter 38: "On the Light Mind and the Apostles and the Saints" (Ke 89.19-102.12)', in Coptica, Gnostica, Manichaica: Mélanges offerts à Wolf-Peter Funk, ed. Louis Painchaud and Paul-Hubert Poirier (Québec: Les Presses de l'Université Laval/Peeters, 20o6), 740. 
(in general) absent, many of the above-examined cues can, in fact, be shown to derive from a specifically Manichaean literary tradition. As Iain Gardner has argued more recently, based on comparisons between the Kellis letters and the preserved fragments of Mani's Epistles, it is possible to discern a Manichaean epistolary tradition in these texts - one building on a Christian one, to be sure, but representing a distinctive development inaugurated by Mani himself. ${ }^{60} \mathrm{In}$ a preliminary article from 2006, on the 'letter of the Teacher' (now P.Kellis VII Copt. 61), Gardner argued that 'Mani's own Epistles acted as something of a model, which was mediated down through conscious imitation by members of the hierarchy'. ${ }^{61}$ In another article from 2013, he restated this argument. ${ }^{62}$ He showed that prayers found in the Kellis letters echo prayers known from the Epistles of Mani, pointed to how the Biblical terms, allusions, and citations found there reflect Manichaean interpretations of Christian concepts, and noted continuities between the Manichaean letters from Turfan and Kellis. He concluded:

6o A recent discussion highlights both the shared background of Manichaean and Christian cues, as well as Manichaean distinctiveness. One concerns a papyrus letter, P. Harr. 107, initially dated to the first half of the third century and considered one of the earliest Christian letters. In 2000, Gardner, Alanna Nobbs, and Malcolm Choat pointed to distinctive elements this letter shared with Kellis letters, which point rather to a Manichaean context (and so a re-dating to the late third/early fourth century). Iain Gardner, Alanna Nobbs, and Malcolm Choat, 'P. Harr. 107: Is This Another Greek Manichaean Letter?', Zeitschrift für Papyrologie und Epigraphik 131 (2000). Their argument was criticised by David G. Martinez, who pointed to parallels to (ps.-)Serapion's Prayer-book. Martinez did not dispute the distinctiveness of the letter, concluding rather: 'This modest rebuttal to the evidence of Gardner, Nobbs, and Choat (ibid.) does not refute their claim, but it does at least suggest for P. Harris 107 and the Kellis Manichaean texts that the phrases common to both could have their ultimate source in the language of liturgy and protective magic.' (David G. Martinez, 'The Papyri and Early Christianity', in The Oxford Handbook of Papyrology, ed. Roger S. Bagnall (Oxford: Oxford University Press, 2009), 6o2). Gardner recently restated the original argument and, adducing more evidence, further argued that the source of the phrases should be sought in Mani's letters. He also made some (tentative) remarks concerning a possible link between Serapion's prayers and the anti-Manichaean polemic ascribed to him ('Once More on Mani's Epistles', 309-10). For a similar case, see the discussion surrounding a Kellis text, P.Kellis vi Gr. 98 , which largely lacks Manichaean - or even Christian - terminology, but which has since been shown to be the 'daily prayer' attributed to Mani. We return to it in Chapter 7 .

61 Iain Gardner, 'A Letter from the Teacher: Some Comments on Letter-Writing and the Manichaean Community of IVth Century Egypt', in Coptica, Gnostica, Manichaica: Mélanges offerts à Wolf-Peter Funk, ed. Louis Painchaud and Paul-Hubert Poirier (Louvain: Editions Peeters, 2006), 322.

Gardner, 'Once More on Mani’s Epistles', 299-308. 
Manichaean letter-writers in late antique Egypt exhibited their allegiance to that community through terminology, turns of phrase, allusions and interpretations that derived from Mani's own scriptures, together with the practice and usage of their teachers in that church. The pre-eminent source of authority was naturally Mani's own Epistles, which acted as a model that on occasion can be shown to have been directly acknowledged by these later authors. ${ }^{63}$

Such characteristic turns of phrase, allusions, and interpretations (i.e. 'cues') include:

- Invocations of divinities with a particular Manichaean significance, such as the Paraclete and the Light Mind (see below).

- Allusions to Manichaean doctrine, such as the functions of the sun and the moon.

- The 'tripartite prayer' formula, as a rule directed to the 'God of Truth', for health in or protection of soul, spirit, and body, representing Mani's reworking of 1 Thess. $5: 23,{ }^{64}$ often combined with a prayer for protection from evil and/or Satan. ${ }^{65}$

- The 'elect and catechumen' formula, greeting 'those who give rest to you, both elect and catechumen'.66

These, then, are the most secure markers of 'Manichaeanness'. Other stylistic features that are less distinctively Manichaean, but that are frequently used in the corpus of Manichaean letters and so potentially in imitation of Mani's Epistles, include:

- The 'embrace' formula, a prayer for a future embrace 'in the body', often with the addendum: 'so that (our/my) joy will be complete'.67

63 Ibid., 308.

64 Gardner, Nobbs, and Choat, 'P. Harr. 107', 122-23 n.7-12; Gardner, 'Once More on Mani's Epistles', 299-300.

65 Iain Gardner, 'Mani's Letter to Marcellus: Fact and Fiction in the Acta Archelai Revisited, in Frontiers of Faith. The Christian Encounter with Manichaeism in the Acts of Archelaus, ed. Jason D. BeDuhn and Paul Mirecki (Leiden: Brill, 2007), 41; id., 'Some Comments on the Remnants of the Codex of Mani's Epistles in Middle Persian as Edited by W. Sundermann', in Zur lichten Heimat: Studien zu Manichäismus, Iranistik und Zentralasienkunde im Gedenken an Werner Sundermann., ed. Team Turfanforschung (Wiesbaden: Harrassowitz, 2017), 176.

66 'Rest' (Gr. $\dot{\alpha} \nu \dot{\alpha} \pi \alpha v \sigma \varsigma$, C. $\bar{M} T \alpha N)$ in the first part of the phrase could allude to Elect asceticism, for which, see e.g. BeDuhn, The Manichaean Body, 37. However, cf. the notes in P.Kellis $V$, 53 .

67 See P.Kellis VII, 109-10. 
- The 'far but near' formula, an expression of emotional closeness despite physical distance ('every time I am far away, it is as if I am near').

- Praises or 'remembrances' of good conduct, good reputation, and other virtues known from Manichaean discourse. ${ }^{68}$

To these we can add two more. First, a reference to people belonging to this/ our 'word' is found twice: in Matthaios' letter P.Kellis v Copt. 25 and Ammon's P.Kellis v. Copt. 37. It is clear that this phrase is used to refer to the shared religious community in these instances, although to what degree it was derived from a distinctly Manichaean literary tradition awaits further investigation. Secondly, the phrase 'whose name is sweet in my mouth', which is frequently conferred by House 1-3 authors on their addressees. It may well be a distinctly Manichaean expression, as it could reflect the relationship between virtuous acts and sensory wellness found in Manichaean discourse (exemplified at Kellis in a word play found in the letter from the Teacher). ${ }^{69}$ A dialectal feature, perhaps peculiar to the L4 variety of Coptic, cannot be excluded, although it has recently been argued that the L4 dialect itself could be peculiar to the Manichaean scribal tradition. ${ }^{70} \mathrm{~A}$ supporting argument is that the expression occurs with a very high frequency in letters that contain other specifically Manichaean cues. ${ }^{71}$ It may be premature to categorise it as a typically Manichaean expression without an example from a

68 Gardner, 'Once More on Mani's Epistles', 300-1. The editors of P.Kellis $V$ list 21 terms for virtues and values found in the Coptic letters, such as love ( $\dot{\alpha} \gamma \dot{\alpha} \pi \eta)$, righteousness ( $\delta$ ix $\alpha \mathrm{l}-$

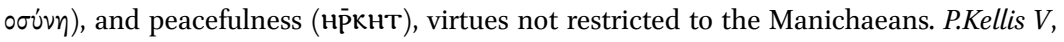
8o; also P.Kellis VII, 35 n.2. The Coptic House 3 letters show some distinct features in the structure of their inner address, such as the placement of the recipient first without an object marker, but nothing suggests that this can be attributed to Mani. See Malcolm Choat, 'Epistolary Formulae in Early Coptic Letters', in Actes du huitième congrès international d'études coptes, ed. Nathalie Bosson and Anne Boud'hors (Leuven: Peeters, 2007), 670.

69 The Teacher plays on the similarity between the words ctwoYye, 'fragrance', and citwoYye, 'good conduct'; P.Kellis VII, 33. For the bodily transformation ostensibly produced by the Manichaean regime, see e.g. keph. 104 (1 Ke. 258.4-25). For the connection between 'fragrance' and the divine Light, traceable to Syriac Manichaean texts, see Nils A. Pedersen and John M. Larsen, Manichaean Texts in Syriac: First Editions, New Editions, and Studies (Turnhout: Brepols, 2013), 226-29.

70 Choat note its possible origin as a dialectical expression, see Malcolm Choat, review of Coptic Documentary Texts from Kellis Volume 2, by Gardner, Alcock, and Funk, eds., Bryn Mawr Classical Review (2016). For the Coptic L* dialect as specific to a (Manichaean) scribal tradition, see Ewa D. Zakrzewska, ' $L$ * as a Secret Language: Social Functions of Early Coptic', in Christianity and Monasticism in Middle Egypt: Al-Minya and Asyut, ed. Gabra Gawdat and Hany N. Takla (Cairo: American University of Cairo Press, 2015).

71 P.Kellis v Copt. 15, 17, 19, 26, 37; P.Kellis vir Copt. 79, 82, 115. For its occurrence in letters without (legible) Manichaean cues, see P.Kellis viI 70, 93, 105, 112, 122. 
Manichaean authority (e.g. one of Mani's Epistles). The well-preserved 'Father letters', attributable to Elect, do not employ it. However, it should probably be restored in a fragmented Coptic text which seems to belong to the same group, P.Kellis viI Copt. 63 (ll.2-3).

It remains true that the most explicit cues, those that invoke Manichaean ideas and divinities, are found in the chief above-mentioned Father letters, i.e. P.Kellis v Copt. 31-33 and P.Kellis I Gr. 63. Their cues include references to the Light Soul, the Light Mind, and the role of the sun and the moon as 'storehouses' of Light. However, in at least three of the letters, the authors are writing to Auditors. ${ }^{72}$ Conversely, the two most readily identifiable Elect in the archive, the Teacher and Apa Lysimachos, do not use easily identifiable Manichaean cues at all in their preserved letters. ${ }^{73} \mathrm{An}$ important caveat is that parts of these letters, notably the opening of Lysimachos' P.Kellis v Copt. 30, are lost or very fragmentary. However, the opening of the Teacher's letter is preserved, and reads:

The Teacher, and the brothers who are with me: To all the presbyters, my children, my loved ones; Ploutogenios and Pebo and all the others [...] according to their names; in the Lord, - greetings. [Now, every] time I am afar it is as if I am near. [I remember] the gentleness of your (pl.) sonship and the strength of your faith. I pray always to Jesus Christ: That he will guard you for me with this fragrance ((excellent conduct)) as you are [honoured] by everyone corresponding to [your] conduct [...]

P.Kellis viI Copt. 61, ll.1-13

Certainly, this passage contains a wealth of religious cues, including the 'far but near' formula and the virtues valued by the community (such as 'gentleness'). There is little reason to doubt that the Teacher was an important religious official, likely the highest Manichaean authority in Egypt; furthermore, Elect presbyters are chief among his recipients. Yet, there is no trace of the most explicit cues: of specifically Manichaean divinities or doctrines, of the 'elect and catechumen' formula, or of the tripartite prayer.

Finally, as evident from the discussion above, allusions to the specifically Manichaean literary tradition was not restricted to the letters of the Elect. In P.Kellis VII, the editors reckoned that, of the 110 Coptic documentary letters published, 23 have: 'reasonably explicit expressions of Manichaean faith, by

72 In P.Kellis v Copt. 31, 32, and P.Kellis I Gr. 63.

73 I.e. the Teacher's P.Kellis vir Copt. 61; Lysimachos' P.Kellis v Copt. 30 and P.Kellis I Gr. 67. 
which we mean reference to "the Paraclete" or the "Light Mind" or suchlike. ${ }^{74}$ In other words, about a fifth of the published Coptic letters from House 1-3 contain distinctly Manichaean cues. ${ }^{75}$ That includes the letters of Elect, to be sure, but 'reasonably explicit expressions' are also found in all the different social circles of House 1-3, excluding only the Petros letters. Certain authors, such as Makarios and Horion, put on rather more elaborate displays than others. These two authors appear particularly engaged with religious affairs and with Elect authorities. However, also authors who are not known to have had such strong links utilise distinctly Manichaean cues. As we have seen in the analysis above, both Pamour III and Pekysis use the tripartite greeting formula, while Tekysis III employed a prayer for 'to embrace him in the body, and my joy will be complete', and closed with a rest-formula. Admittedly, their cues do not use direct references to Manichaean myths or beliefs. ${ }^{76}$ Still, religious cues do not necessitate explication. They make allusion a virtue, and derive their impact on group identity from calling to mind the implicit, shared knowledge of a symbolic repertoire - in this case, one ascribed to Mani. The cue usage of the lay authors of House 3 clearly suffice to suggest a distinctly Manichaean identity.

$74 \quad$ P.Kellis VII, 13.

75 By my count, there are 24 letters - 23 Coptic (presumably the 23 noted by the editors, although they do not list them) and one Greek: P.Kellis v Copt. 14-17, 19, 22, 25, 29, 31-36; P.Kellis viI Copt. $61-62,65,71-72,78,85,89$, 115, and P.Kellis I Gr. 63. The expressions I count as 'reasonably explicit' are the 'tripartite prayer', references to 'giving rest' by Elect and/or Catechumen, invocations of the God of Truth, the Paraclete, the Light Mind, or the Light Soul, labels such as 'children of righteousness' or 'fruit of the good tree', and the 'far but near' formula. Several other letters deploy phrases that could, perhaps, be derived from the Manichaean epistolary tradition, but have not been proved as such, as discussed above. These include the expression 'whose name is sweet in my mouth', prayers for protection against Satan or 'evil', longing to 'embrace each other in the body', and perhaps the exclamation 'service of God!' (for the latter, see P.Kellis $V, 80$ ).

$7^{6}$ As noted by Brand. While acknowledging their likely debt to Mani, he writes in relation to the prayer formulas that they 'hardly contain explicit and exclusive Manichaean language ... it is noteworthy that most of the explicit Manichaean terminology came from either the elect or from those who travelled with them.' Brand, 'Manichaeans of Kellis', 152. Still, while the latter assertion is true for the Elect with regards to the 'Father letters', it does not hold for those of Apa Lysimachos or the Teacher. Nor can we know that the lay figures who use the most explicit Manichaean cues, Makarios and Horion, travelled with Elect, although they were clearly in close touch. On the other hand, Philammon II, travelling with Lysimachos in P.Kellis viI Copt. 82, employs less explicit cues. 
One might still reasonably ask whether, or to what extent, the lay people were aware of more specifically 'Manichaean' traditions. It could, perhaps, be argued that the Auditors simply imitated Elect usage, without necessarily being conscious of the cues' derivation. Direct imitation of Elect letters by the Auditors cannot be shown on present evidence, as Brand's analysis of religious language in the Kellis letters has demonstrated, ${ }^{77}$ but is not necessarily implausible. We may therefore consider whether the letters evince more 'conscious' engagement with Manichaean notions, as far as this can be determined from the evidence. Below, we therefore examine two cues - 'the Light Mind' and 'the flourishing tree' - used by lay adherents in order to throw light on this question.

Let us start with the Light Mind. In the 'theology' of the authoritative Manichaean tradition, this figure was considered a crucial divinity, responsible for some of the most important work of the forces of Light on earth. ${ }^{78}$ It was he who, when invited by the soul, entered human bodies, chained the demons inhabiting them, and transformed 'old humans' into 'new humans'. This process is described in detail in one of the longest chapters of the Berlin Kephalaia, keph. 38. In turn, this chapter shares numerous features with a text entitled The Sermon on the Light Mind, found in various languages at Turfan. Both keph. 38 and the Sermon must have drawn on material from a canonical work of Mani, probably his Book of Giants, ${ }^{79}$ and so the importance of the Light Mind clearly goes back to the earliest period of the movement. In keph.

77 Brand includes a wider range of religious cues in his analysis, not limited to specifically 'Manichaean' ones, but finds no pattern indicating direct Elect-Auditor transmission. See Brand, 'Speech Patterns', 114, 118.

78 For a survey of its occurrences in the Medinet Madi texts, see Lindt, Mythological Figures, $154-69$.

79 Werner Sundermann, Der Sermon vom Licht-Nous: Eine Lehrschrift des östlichen Manichäismus Edition der parthischen und soghdischen Version (Berlin: Akademie Verlag, 1992), 13-15. Mani's Picture-book is said to have contained a painting of this divinity, and its iconography has been reconstructed from Uighur and Chinese art in Zsuzsanna Gulácsi, Mani's Pictures. The Didactic Images of the Manichaeans from Sasanian Mesopotamia to Uygur Central Asia and Tang-Ming China (Leiden: Brill, 2015), 356-74. All these different traditions are concerned with evil - pre-eminently the supposedly perfect Elect. 'The vexing experience that the powers of darkness keep rebelling against the New Man must have been of great concern for everyday life in Manichaean communities.' Werner Sundermann, 'Mani's Book of the Giants and the Jewish Books of Enoch. A Case of Terminological Difference and What It Implies', in Manichaica Iranica. Ausgewählte Schriften von Werner Sundermann, ed. Christiane Reck, et al. (Rome: Istituto italiano per l'Agrica e l'Oriente, 2001), 705 . 
38, the Light Mind is depicted as suppressing five evil qualities and inserting five good virtues into the five 'soul limbs' of the human body. By this work, the Light Mind 'shall set right the members of the soul; form and purify them, and construct a new man of them, a child of righteousness' (1 Ke. 96.25-27). The presence of the Light Mind, then, produces children of righteousness: Elect who, through their bodily discipline, themselves assist in freeing divine light from the earth. Another chapter, keph. 7, presents the Light Mind also as a soteriological divinity, saving souls through an emanation of his own called the 'Light Form', which met the soul on its release, fought off demons, and brought it safely to the other divinities of redemption (1 Ke. 36.9-11).

The Light Mind was, in other words, of great importance for the individual, helping to free their souls and transform their bodies into vehicles of salvation for themselves and others. At the same time, it played an analogous role for the social body of the Church. Keph. 7 describes the Light Mind as 'the father of the apostles, the eldest of all the Churches' (1 Ke. 35.21-22). This role it played through its emanation of the 'Apostle of Light', a spirit that inhabited human Apostles, who in turn chose the 'Church of the flesh' (1 Ke. 36.4-5) ${ }^{80}$ The last of the Apostles, Mani, had chosen a 'good election, the Holy Church' (1 Ke. 16.3-4), which was to be the truly last Church. ${ }^{81}$ The Light Mind came to dwell in and guide this Church, binding it together. This communal function of the Light Mind goes back to Mani himself: in a letter-fragment preserved from the Medinet Madi Epistle Codex, given in preliminary translation by Gardner, Mani states that: 'He (Jesus Christ) is the one who can bless you all, my children, my loved ones: For he can place his love in your [... which] is the Light Mind'. ${ }^{82}$ Certainly, according to later authorities, it was Mani who placed the Light Mind in the Church. ${ }^{83}$ Keph. 63 even states that the Light Mind had

8o For a different interpretation of the prophetology described in this passage, maintaining that 'Apostle' only applies to Mani, see de Albert de Jong, "A quodam persa exstiterunt": Re-Orienting Manichaean Origins', in Empsychoi Logoi. Religious Innovations in Antiquity: Studies in Honour of Pieter Willem van der Horst, ed. Alberdina Houtman, Albert de Jong, and Magda Misset-van de Weg (Leiden: Brill, 2008), 97-98. However, Mani also speaks of previous 'Apostles' elsewhere, e.g. in keph. 122 (1 Ke. 295.5), and see also keph. 143 (1 Ke. 346-347), which relates explicitly that a single 'power' is behind all the Apostles.

81 See also keph. 151 (1 Ke. 371.31-372.10).

82 Provisional translation in Iain Gardner, 'The Reconstruction of Mani's Epistles from Three Coptic Codices (Ismant el-Kharab and Medinet Madi)', in The Light and the Darkness, ed. Paul Mirecki and Jason D. BeDuhn (Leiden: Brill, 2001), 100. For 'love' as an injunction laid upon the hierarchy of the Church, see the epistle of Mani found at Kellis and preserved in P.Kellis vi Copt. 54 (cited in Chapter 7).

83 A tradition found in the Medinet Madi Acts Codex stated that Mani had, on his deathbed, reassured a woman named Nushak that his 'Mind' would remain in the Church. 
become the Church, the two having united through Mani's love and sacrifice. ${ }^{84}$ Since salvation depended on the assistance of the Light Mind, and as the Light Mind and the Holy Church were one, rituals had to be performed within the Holy Church in order to be able to free souls. ${ }^{85}$ In this way, Manichaean authorities depicted the Church they represented as the only locus of salvation.

This is the Light Mind as elaborated by church authorities. How does it relate to the divinity found in the letters at Kellis? While the evidence is sparse, there is to my mind good reasons to suspect that the Kellites knew some of the important characteristics of this divinity. The Light Mind occurs twice in the documentary texts. As already cited, Horion greets his 'brother' Horos as 'the son of righteousness, the good limb of the Light Mind' in P.Kellis $\mathrm{V}$ Copt. 15. His usage of 'limb of the Light Mind' as an identity label is, to my knowledge, not directly paralleled in the Medinet Madi corpus. And yet, his usage sits remarkably well with the identification of the Light Mind and the Church described above. Adherents are at times presented as 'limbs' of the Church. ${ }^{86}$ When united, the Church and the Light Mind represented an extension of Mani himself, who is often found addressing his followers as 'my limbs' in the Berlin Kephalaia. ${ }^{87}$ Members of the Church could therefore easily be considered limbs of the Light Mind. The association of the two labels, 'child of righteousness' and 'limb of the Light Mind', is, moreover, strongly reminiscent of the passage from keph. 38 , where becoming a 'child of righteousness' is the result of being freed by the Light Mind. Horion's phrasing would seem to allude to a particular Manichaean conception of the relationship between 'child of righteousness', Light Mind, and membership of the 'Church'. This is supported by a similar expression used in P.Kellis v Copt. 31, written by an anonymous Elect, 'your Father who is in Egypt', to a group of lay women whom he describes as 'members (M€入oc) of the Holy Church, [daughters] of the Light

See Polotsky, Schmidt, and Ibscher, 'Ein Mani-Fund', 26-27. See also e.g. 1 Ke. 148.7-15; 2 Ps. 171.22, and CMC 17.2-7. It seems to represent a reworking of the union of Christ and Church in Eph.5.26-32, applied to Mani.

84 'These two, the Mind and the Church, a single body is also their likeness; because, again, the apostle too shall give his own self for his church. And again, due to this, the church too calls him "love"' (1 Ke. 156.10-14).

85 See keph. 38 (1 Ke. 79.13-81.20), keph. 87 (1 Ke. 217.6-11), and BeDuhn, The Manichaean Body, 206-7. The role of the Light Mind in making ritual effective is made explicit in keph. 75. See also Psalm 227, where the singers request to 'receive the Holy Seal (сфрдгıс eтоүаве) from the Mind of the Church' (2 Ps. 22.11).

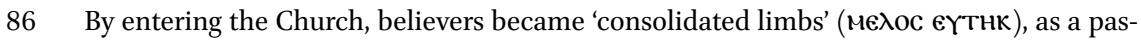
sage from keph. 149 (1 Ke. 357.9) puts it. See also SNC (Hom. 85.26).

$87 \quad$ E.g. 1 Ke. 34.6, 213.3, and 285.21. 
Mind' (ll.2-4). This greeting provides an even more explicit allusion to the unity between Holy Church and Light Mind, if in this case by an Elect.

Next, let us consider the image of the 'good tree', which is also employed in two letters: P.Kellis v Copt. 22, by Makarios, and P.Kellis v Copt. 32, by a 'Father'. Makarios greets his addressees Maria, Psenpnouthes, and Kyria, as (amongst others): 'fruits of the flourishing tree, blossoms of love' (P.Kellis $\mathrm{V}$ Copt. 22, ll. 5-6). While ultimately derived from Jesus' parable of the two trees (e.g. Matt. 7.15-20), the tree was a malleable symbol within the Manichaean tradition, used for instance in connection with the Kingdom of Light or with cosmic wisdom. It also specifically related to the Church and its members. This usage is found already in Mani's own exposition of Jesus' parable, at least as presented in the second chapter of the Berlin Kephalaia. Mani here equates the 'good tree' with the God of Truth, his emanations, and the Land of Light, the 'bad tree' with Matter, Satan, and their realm, and describes the Churches established by the Apostles (Buddha, Zarathustra, Jesus, Paul, Mani) as fruits of the 'good tree' (1. Ke. 19.30-22; also e.g. 13.35-14.2).88 Makarios' phrase resonates with, but is not directly comparable to, this notion: rather than Churches, he depicts fellow adherents as 'fruits'. However, his mode of expression finds its direct counterpart in certain psalms, such as Psalm 249, where the Church is called the 'good tree' and the individual believer its 'fruit' (2 Ps. 58.9-10). To this we can compare the use made of this expression by the Elect Father in P.Kellis v Copt. 32, writing to the Auditor Eirene. His usage is not directly derived from Mani's exposition of the parable either, but represents a different adaption again: he likens Eirene herself to the 'good tree' and her good deeds to 'fruits', a metaphor that is also found in the Manichaean psalmody. ${ }^{89}$ Makarios' use of the 'good tree' metaphor, then, is clearly firmly rooted in the Manichaean symbolic repertoire. Still, he does not transmit it mechanically, but has selected a particular metaphor that suited his purpose, emphasising their shared Manichaean identity.

88 The metaphor likening the two trees to the two realms probably goes back to Mani; it is found in Severus of Antioch's 123rd Cathedral Homily (150.7-14), see Samuel N. C. Lieu, et al., eds., CFM Series Subsidia: Greek and Latin Sources on Manichaean Cosmogony and Ethics (Turnhout: Brepols, 2010), 29. I owe this reference to one of my anonymous reviewers. For recent work on the source of Severus' citations, thought to be one of Mani's own works (perhaps The Living Gospel), see John C. Reeves, 'Further Textual Evidence Pertaining to the Enigmatic "Mani-Citations" of Severus of Antioch', in Open Theology 1 (2015).

89 For instance, 2 Ps. 40.2-3, 91.8-13, 175.8-9. Eirene's 'good deeds' are in turn linked with almsgiving; see the analysis in Chapter 8, Section 2.3. 
Perhaps it could be objected that the cues can only be taken to reflect the engagement of their authors. We do not know with certainty what Horos I, Maria I, or the women addressed in P.Kellis v Copt. 31 and 32 read into labels such as 'limbs of the Light Mind' or 'child of righteousness'. Authors addressing such audiences often engage in scripting identities both for themselves and the recipients, and it is not a given that the latter accepted or understood such scripts on the same terms as the authors. ${ }^{90}$ At the same time, it is highly unlikely that the addressees were unfamiliar with or disapproved of these scripts in the present instances. Horos I himself shared in organising the agape, clearly a religious obligation. Maria I's co-recipient, Kyria I, was in possession of religious books (Mani's Epistles likely among them), and Makarios' appeal to Maria I's (or Kyria I's) status as 'catechumen', discussed above, shows that he took it for granted that she shared in a broadly similar understanding of this role. The women who received P.Kellis v Copt. 31-32 were extolled for previous services to the Church, and the 'Fathers' who wrote to them clearly had reasonable expectations that they would respond positively to these cues.

The above analysis is intended to show that, while rooted in Christian texts and traditions, the religious cues of the Kellites have a more immediate background in a distinct Manichaean symbolic repertoire, which they adapt consciously in their own writings. Furthermore, they are tied to clusters of metaphors associated with the community itself, the 'Holy Church', and strongly suggest that the writers are signalling affiliation with the same authoritative tradition that produced the Medinet Madi texts: the 'Holy Church of the Paraclete', as it is called in Medinet Madi Psalm 222. This psalm has, in fact, been partly preserved at Kellis. As we shall see in Chapter 7 , the Pamour family had access to explicitly Manichaean literature, which was embedded in the ritual life of the community and which could well have served as pools from which these authors drew to formulate their cues. We cannot, of course, take this to mean that they were familiar with the whole scheme of Manichaean myths and divinities, with the detailed depiction of the Light Mind's role or with Mani's exposition on the 'good tree' as found in the Kephalaia. Nonetheless, the cues do show conscious engagement with a distinctly Manichaean tradition, on which the lay people at Kellis drew to articulate their religious identity. 


\section{Conclusions}

To conclude, in the course of this chapter we have seen how the people of House 1-3 considered their religious identity to be salient beyond what we may term specifically religious settings. The cues which they used to invoke this shared identity drew on a distinctly Manichaean symbolic repertoire, and their usage should lead us to conclude that a distinctly Manichaean identity played a role - even a comparatively important role - in the everyday lives of the House 3 families. Certainly, this is not to say that Manichaean identity was their 'primary' identity. It was neither uniform nor all-encompassing. There would have remained many occasions on which it would not have intruded, and, on those occasions it did, the extent to which it was given saliency would have varied, both on the individual level and between different subgroups. ${ }^{91}$ We may catch a glimpse of such internal variation in the letters from House 3: although the family grouping of Pamour/Pekysis did utilise religious cues in a variety of settings, and clearly considered their Manichaean affiliation important, they were less immersed in its vocabulary than the family grouping of Maria/Makarios. ${ }^{92}$ However, these points do not negate the conclusion above. By putting too much stress on individualised appropriation, we risk losing sight of the significance, and, indeed, attraction, that shared identity could hold, also among the laity.

91 BeDuhn's recent study on Augustine's and his mentor Faustus' different approaches to Manichaean identity provides a good example of individualised adaptions. See Jason D. BeDuhn, 'Am I a Christian? The Individual at the Manichaean-Christian Interface', in Group Identity and Religious Individuality in Late Antiquity, ed. Éric Rebillard and Jörg Rüpke (Washington, DC: The Catholic University of America Press, 2015). 